\title{
THE SOURCE OF HYDROGEN SULFIDE IN ANOXIC SEDIMENT
}

\author{
David A. Dlisetre*t, David P. Chynoweth + and Khalil H. Mancy \\ Department of Environmental and Industrial Health, The University of Michigan. Ann Arbor, MI 48104. \\ U.S.A.
}

(Receiced June 1984)

\begin{abstract}
Putrefactive hydrogen sulfide production in the upper $4 \mathrm{~cm}$ of sediment in two small freshwater and eutrophic Southeast Michigan, U.S.A., lakes ranged from 0.13 to 1.51 with an average of $0.46 \mathrm{mg}$ $\mathrm{S}^{-1} \mathrm{day}^{-1}$. Sulfate reductive production of hydrogen sulfide at the same sites ranged from 0.7 to 3.2 with an average of $1.54 \mathrm{mg} \mathrm{S}^{-1} \mathrm{day}^{-1}$. Putrefactive hydrogen sulfide production represented $5.1-53^{\circ}$ (average of $18.3-27.6 \%$ ) of the total hydrogen sulfide produced at the two lakes over an April-October study period. "S labeled substrates were used to estimate hydrogen sulfide production rates.

Proteolytic bacteria averaged $2.2 \times 10^{4}$ cells $\mathrm{ml}^{-1}$ sediment whereas sulfate reducers averaged $4.8 \times 10^{-}$ cells $\mathrm{ml}^{-1}$ sediment. Putrefactive hydrogen sulfide production correlated highly with numbers of proteolytic bacteria $\left(r^{2}=0.84\right)$ but the correlation between sulfate reduction and sulfate reducing bacteria was low $\left(r^{2}=0.13\right)$.

Interstitial soluble inorganic sulfate, protein and organic carbon were not closely correlated with hydrogen sulfide production rates or bacteria enumeration results. Natural substrate concentrations $\left(S_{n}\right)$ used to estimate hydrogen sulfide production were supported by kinetic bioassay results.
\end{abstract}

Key words-hydrogen sulfide, source, sediment, anoxic, putrefaction, sulfate reduction, bacteria

\section{INTRODUCTION}

Hydrogen sulfide is an exceedingly important substance in the aquatic environment. Its presence and reactions rank with photosynthesis, algal respiration, and the iron cycle in the establishment of the electron (Eh) and proton $(\mathrm{pH})$ activity of the aquatic environment (Bass Becking et al., 1960). Hydrogen sulfide is an extremely active chemical and biochemical participant in these biogeochemical transformations.

Sedimentary production of hydrogen sulfide can increase the oxygen demand rate of sediment leading to a reduction in dissolved oxygen in overlying waters. Hydrogen sulfide is toxic to fish and macroinvertebrates particularly at $\mathrm{pH}$ 's $<7$ when $50-100 \%$ of the hydrogen sulfide present is in the undissociated form, $\mathrm{H}_{2} \mathrm{~S}$. Acute toxicity to rainbow trout and sensitive macroinvertebrates occurs at 0.0087 and $0.20 \mathrm{mg} \mathrm{l}^{-1}$ hydrogen sulfide respectively (Smith $e t$ al., 1976). The $\mathrm{LD}_{50}$ in cats was found to be as low as $25 \mu \mathrm{g} \mathrm{kg}^{-1}$ (Lovatt Evans, 1967). Hydrogen sulfide has been associated with corrosion to concrete sewers (Parker, 1945), cooling water towers (Taylor and Hutchinson, 1947), stone (Phochon et al., 1951) and metal pipe (Postgate, 1959). There has been considerable recent environmental health interest in the role of natural sources of hydrogen sulfide in the for-

* To whom correspondence should be sent.

+Present address: College of Science, Portland State University, Portland, OR 97207, U.S.A.

†Present address: Institute of Gas Technology, 3424 South State Street. Chicago, IL 60616. U.S.A. mation of sulfur oxides and sulfuric acid aerosol near coastal environments (Servant and Delaport, 1982; Hitchcock et al., 1980; Rice et al., 1981; and Goldberg et al., 1981).

It has generally been accepted that the only significant route of hydrogen sulfide production in the aquatic environment is sulfate reduction, the microbial reduction of higher oxidation state inorganic sulfur, primarily sulfate, which serves as the terminal electron acceptor from the anaerobic oxidation of organic matter in the respiratory process. The principal sulfate reducing bacterium is $D e$ sulfovibrio desulfuricans. However, it is common knowledge that hydrogen sulfide is a product of the microbially-mediated anaerobic decomposition of the sulfur fraction of proteinaceous matter (putrefaction) and there is evidence that putrefaction can play a very significant role in hydrogen sulfide production in anoxic sediment under some conditions (Nriagu, 1968; Gunkel and Oppenheimer, 1963; Koyama and Sugawara, 1953; Ivanov and Terebkova, 1959). A primary reason for the inattention given to putrefaction is that most work on hydrogen sulfide production in natural waters has been conducted on waters or lakes with high mineral content in which sulfate reduction predominates and the sedimentary content of protein would be small relative to shallow freshwater lakes. In addition, there are no generally accepted methods for assessing the role of protein or protein derivatives in hydrogen sulfide production as with sulfate reduction where the use of ${ }^{33} \mathrm{~S}$ labeled sulfate has been widely used for over 25 years in the 
Soviet Union due to concerns about high soluble sulfide accumulations in stagnant waters with relatively high dissolved minerals.

The purpose of the investigation described here was to obtain direct experimental evidence on the relative importance of putrefaction and sulfate reduction in the freshwater sedimentary milieu. In order to accomplish this, a method analogous to the $35_{\mathrm{s}}$ method of measuring sulfate reduction (Ivanov. 1956. 1968. 1978) was required. The method developed was use of "S labeled cysteine (HS- $\mathrm{CH}_{2}-\mathrm{CH}\left(\mathrm{NH}_{2}\right.$ ) $\mathrm{COOH}$ ) the only sulfhydryl amino acid and the only sulfhydryl compound likely to occur in biogeochemically significant concentrations (Freney, 1967). Although another sulfur bearing amino acid, methionine $\left(\mathrm{CH}_{3}-\mathrm{S}-\mathrm{CH}_{2}-\mathrm{CH}-\mathrm{CH}\left(\mathrm{NH}_{2}\right)\right.$ $\mathrm{COOH}$ ), occurs in concentrations similar to those of cysteine, the principal identified natural sulfur bearing decomposition products include methyl mercaptan, dimethyl sulfide and dimethyl disulfide (Frederick et al., 1957; Tarr, 1933; Kadota and Ishida, 1972; Salsbury and Merricks, 1975; Segal and Starkey, 1969). Although Zinder and Brock (1978) found evidence for $\mathrm{H}_{2} \mathrm{~S}$ formation from methionine in incubated sediment, the total natural plus labeled substrate in their studies was $1-3$ orders of magnitude below that used in this and the aformentioned investigations. Added labeled cysteine in this study was, on the average, approx. $30 \%$ of the natural cysteine. The anaerobic decomposition mechanism for cysteine has been better characterized and includes hydrogen sulfide as its sole sulfur bearing putrefactive product (Fromageat, 1951; Young and Maw, 1958; Kadota and Ishida, 1972).

Therefore, for the purposes of this study the terminal sulfhydryl amino acid cysteine was assumed to be the primary hydrogen sulfide producing organic substance occurring in biogeochemically significant quantities in freshwater sediment and anaerobic decomposition of "S labeled cysteine was accepted as representing putrefaction.

\section{EXPERIMENTAL}

Lakes used in the study.

Most samples were taken from Third Sister Lake, a 10.0 acre lake located in southeastern Michigan and typical of the many glacially originated lakes found throughout Michigan and the northern midwestern states. The sediment at the west end of the lake is primarily clay while that at the east end is silty clay. The average composition of the sediment at depths of $7-15 \mathrm{~m}$ is $40 \%$ silt and $45 \%$ clay. The water supply comes primarily from seepage and runoff originating in the surrounding moraines. There is no permanent inlet or outlet to Third Sister, a moderately eutrophic lake.

Samples of sediment were taken from two stations located at opposite sides of the lake. West station had a depth of $15 \mathrm{~m}$ and East station was $10 \mathrm{~m}$ deep. The actual point of sample withdrawal varied within a radius of approx. $1.5 \mathrm{~m}$ for each station. A larger, more eutrophic and shallow lake. Frain's Lake, was used for the collection of a small number of samples for comparison with those taken from Third Sister. Frain's Lake supports massive algae blooms in early summer and its upper sediment has less clay and consid. erably more pulpy peat than Third sister. Samples were taken from a $9 \mathrm{~m}$ station located in the lake center.

\section{Sampling}

A method was developed which allowed sampling of the upper $5-10 \mathrm{~cm}$ of sediment at any lake depth in a relatively unaltered state. The sampling apparatus used in this study consisted of a large modified $200 \mathrm{ml}$ plastic syringe (Hasbro Industries, Pawtucket, RI) adapted to the weighted upper end of a $4 \mathrm{~cm}$ core extractor (Hydro-products, San Diego, CA). The bottom of the syringe was sharpened with a file to facilitate penetration into the sediment. After removing the plunger the syringe (Fig. 1) was affixed to the coring device by a tight fitting $10 \mathrm{~cm}$ piece of $4.5 \mathrm{~cm}$ dia polyethylene cylinder (cut from a bottle of this size). Hose

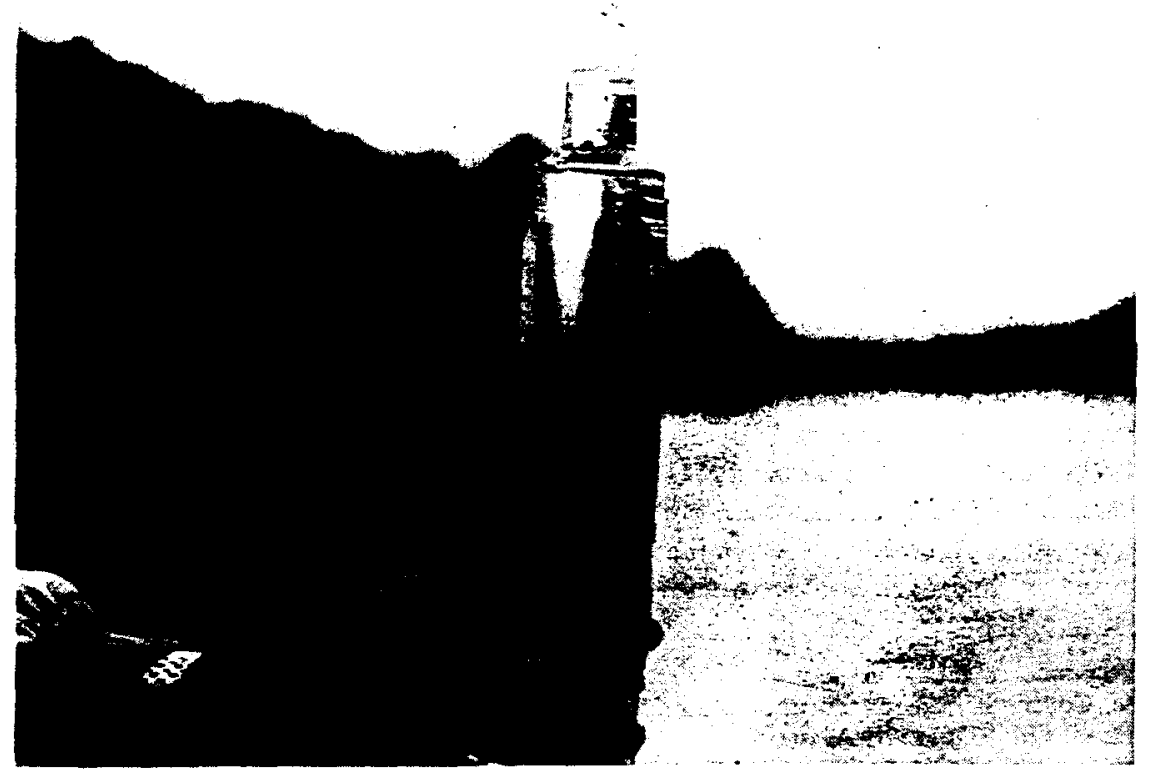

Fig. 1. Sample syringe after detachment from corer. 
clamps were used to tighten the syringe to the corer assembly.

To obtain a sample the corer assembly was let down slowly into the water until contract was made with the sediment. After a few seconds the device was raised to the surface and the plunger inserted into the sampler syringe while the bottom of the syringe unit remained about $5-8 \mathrm{~cm}$ under water. Sediment in excess of the required volume was extruded as waste. The sampler syringe was fitted by means of Tygon tubing to a standard $50 \mathrm{ml}$ plastic disposable syringe with Luer-lok tip (Becton, Dickson \& Co., Rutherford. $\mathrm{NJ}$ ) the orifice of which had been previously drilled out to approx. $4 \mathrm{~mm}$. Sediment was readily transferred with a downward depression of the large syringe and a concurrent pull of the sample receptor syringe. Knowing the diameter and volume of both syringes, the volume of sediment equivalent to the core of given depth could be determined. The volume of sediment taken in these experiments, $50 \mathrm{ml}$. represented the upper $4 \mathrm{~cm}$.

\section{Disposition and manipulation of sample}

Immediately after sampling. the filled syringes were placed in a precooled Dewar flask and transported to the laboratory at a temperature of $5-10^{\circ} \mathrm{C}$. At the laboratory. sediment samples were homogenized so that each aliquot taken would represent the whole sample. This was accomplished by repeated displacements from one $50 \mathrm{ml}$ disposable syringe to another through a $2 \mathrm{~cm}$ piece of $5 \mathrm{~mm}$ heavy wall Tetlon or polyethylene tubing. Thirty cycles or a total of 60 displacments (based on tracer studies) were found to be adequate to fluidize and homogenize samples.

To allow more accurate delivery, sediment was transferred from the $50 \mathrm{ml}$ syringes to each of two $5 \mathrm{ml}$ previously-drilled plastic disposable syringes for each station sampled. As with original transfers from the corer, care was taken to avoid inclusion of air. This was accomplished

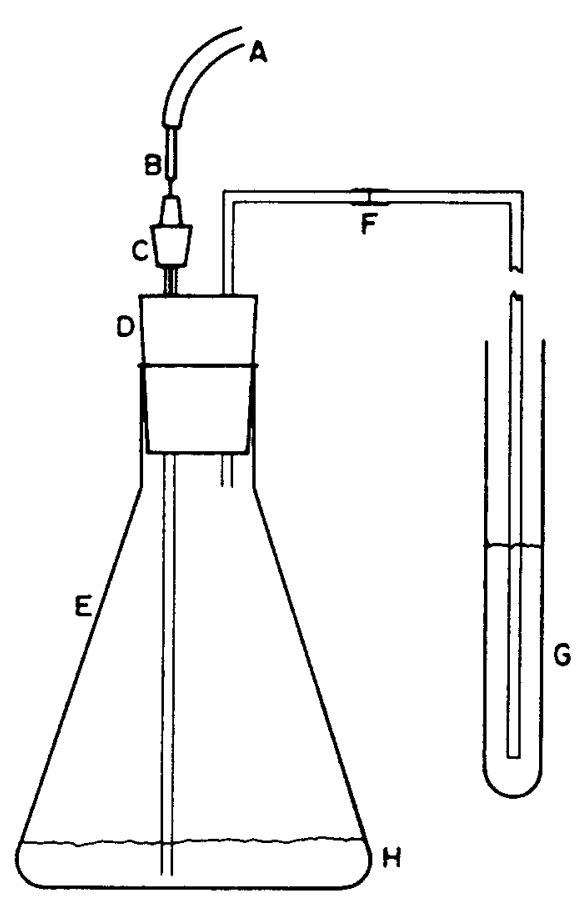

Fig. 2. Apparatus for distillation of $\mathrm{H}_{2} \mathrm{~S}$ from sediment. (A) Nitrogen delivery tube; (B) B \& D No. 21Gl disposable needle; (C) $5 \mathrm{~mm}$ dia serum bottle sleeve; (D) No. 0 two hole stopper enclosed within No. I polyethylene stopper; (E) $25 \mathrm{ml}$ Erlenmeyer flask: (F) $2 \mathrm{~mm}$ i.d. glass tubing connected to delivery tube with Teflon tubing: $(G)$ cadmium acetate solution: $(\mathrm{H})$ sediment in $6 \mathrm{~N} \mathrm{HCl}$. by (1) connecting a $2 \mathrm{~cm}$ piece of $4 \mathrm{~mm}$ poleythylene tubing to a $50 \mathrm{ml}$ syringe. (2) filling the tube with sediment by depression of the plunger. (3) connecting a $5 \mathrm{ml}$ syringe to the other end of the poleythylene tubing and (4) holding the connected syringes in a vertical position with the $5 \mathrm{ml}$ syringe on the bottom. The plungers were reciprocally depressed for a total of 5 cycles while strongly supporting the bodies of the syringes so as to avoid separation under the resulting pressure. Each of two syringes were filled with approx. $5.5 \mathrm{ml}$ of sediment. Of the remaining homogenized sediment. $1 \mathrm{ml}$ was taken for bacteria enumeration, $10 \mathrm{ml}$ for $\mathrm{Eh}$ and $\mathrm{pH}$ measurements and the rest stored at $-20^{\circ} \mathrm{C}$ for later analysis of sulfate, cysteine, protein and organic carbon. After transfer. the $5 \mathrm{ml}$ syringes of sediment were capped and temperature equilibrated in a Dewar Hask water bath maintained at $10 \pm 0.5 \mathrm{C}$.

\section{Estimation of hydrogen sulfide production rates}

The primary analytical technique employed in this study was anaerobic incubation of sediment inoculated with ${ }^{35} \mathrm{~S}$ labeled cysteine or sulfate at $10^{\circ} \mathrm{C}$. After $15 \mathrm{~min}$ of temperature equilibration, syringes filled with sediment were brought to the $5.0 \mathrm{ml}$ mark and labeled ${ }^{35} \mathrm{~S}$ substrate was inoculated into the sediment through the syringe orifice. A measured volume of $15-20 \mu 1$ of $2-10 \mu \mathrm{Ci} \mu !^{-1}$ with a substrate concentration of $0.06-0.30 \mu \mathrm{g} \mathrm{S} \mu \mathrm{I}^{-1}$ for cystine and $0.22-1.10 \mu \mathrm{g} \mathrm{S} \mu \mathrm{I}^{-1}$ for sodium sulfate was employed. Cystine was used rather than cysteine, but under Eh values observed for all sediment samples, cystine is converted immediately to cysteine, the form from which hydrogen sulfide is directly liberated (Freney. 1967).

After inoculation, a second $5 \mathrm{ml}$ syringe was affixed to each original syringe (separate syringes were used for cystine and sulfate for estimation of putrefaction and sulfate reduction respectively). The substrates were mixed into the sediment samples by reciprocal depression of syringe plungers for a total of 30 cycles. The time noted after this operation was taken as $T=1 \mathrm{~min}$. Within two minutes $1 \mathrm{ml}$ aliquots were injected into $25 \mathrm{ml}$ Erlenmeyer flasks containing $2 \mathrm{ml}$ of $0.1 \mathrm{M}$ cadmium acetate. This fixed all free hydrogen sulfide and ionic sulfide in the form of cadmium sulfide. The time of this fixation was noted. Additional aliquots were taken as required, generally 3 or 4 over a $60-120 \mathrm{~min}$ period. Immediately after the incubation period the flasks were arranged in a bank. fitted with distillation units as shown in Fig. 2 and purged for $5 \mathrm{~min}$ with $\mathrm{O}_{2}$ free nitrogen. After purging. the nitrogen delivery needles were removed from the attached septa and $5 \mathrm{ml}$ of $6 \mathrm{~N} \mathrm{NCl}$ was added, after which the nitrogen flows were resumed at a rate of approx. $25 \mathrm{ml} \mathrm{min}-1$ for $30 \mathrm{~min}$. The hydrogen sulfide resulting from acidification of sediment was flushed into $18 \times 150 \mathrm{~mm}$ test tubes containing $12 \mathrm{ml}$ of $0.1 \mathrm{M}$ cadmium acetate. One to two $\mathrm{ml}$ of iron sulfide rich Third Sister sediment was added to Frain's Lake samples to act as carrier during sulfide distillation due to insufficient natural sulfide content of that sediment. The delivery tubes were washed into the test tubes and the CdS formed in the tubes was collected on $47 \mathrm{~mm} 0.45 \mu$ membrane filters.

Membrane filters were air dried 60-90 min and attached to standard $0.5 \times 5 \mathrm{~cm}$ dia counting planchets with a minimum amount mucilage glue. Care was taken to avoid wetting of the cadmium sulfide layer. Planchet mounts prepared in this way may be used repeatedly with insignificant contamination. Background counts were run on all reused planchets. The mounted filters were allowed to air dry $l \mathrm{~h}$ before counting. This procedure resulted in very homogenous layers of cadmium sulfide. Quicker drying or cadmium sulfide deposition in excess of $1 \mathrm{mg}$ $\mathrm{cm}^{-2}$ occasionally resulted in cadmium sulfide flaking, but normally this was not a problem. Ten minute counts were obtained on a Beckman Low Beta counter in the NET mode. Efficiency of the counter with respect to ${ }^{35} \mathrm{~S}$ was 
$25-35^{\circ}$. In the present work, beta activity self absorption was not a problem since the maximum mass of cadmium sulfide deposited on membrane filters was $0.1-0.5 \mathrm{mg} \mathrm{cm}^{-2}$. This is considerably below the maximum allowable value of $2.2 \mathrm{mg}$ cadmium sulfide $\mathrm{cm}^{-2}$ (Ivanov. 1968). Beyond this value, self adsorption must be considered. Recovery of cadmium sulfide was $99^{\circ}$. Hydrogen sulfide production rates were calculated using the expression of Parsons and Strickland (1962) as modified by Hobbie and Crawford (1969). Isotope correction was not required based on the work of Nakai and Jensen (1964).

Purity of the labeled compounds was checked by chromatography. Chemical purity of cystine was validated by means of thin layer chromatography on silica gel. $R_{f}$ values obtained with a solvent system of $96^{\circ} \% \mathrm{EtOH}, \mathrm{H}, \mathrm{O} 7: 3 \mathrm{v} / \mathrm{v}$. as developed with ninhydrin and acetic acid indicated the absence of detectable impurities such as cysteic acid. The ninhydrin developed cystine spot accounted for approx. $90^{\circ}$ of the beta activity. The quantity of cystine supplied by the manufacturer was confirmed by spectrometric ninhydrin determination.

The concentration of sulfate in the sodium sulfate stock solution was identical with that calculated from the data given. Ion exchange chromatography of labeled sulfate on Dowex 1 as eluted with $0.1 \mathrm{~N} \mathrm{NaNO}$ indicated the absence of significant radiochemical impurity.

\section{Determination of sulfate in sediment}

Inorganic sulfate was estimated by the hydriodic acid digestion procedure of Johnson and Nishita (1952) as modified by Johnson and Arkley (1954) and Steinbergs et al. (1962). The method measures both inorganic and organic sulfate as hydrogen sulfide which is then determined spectrophotometrically as methylene blue. Although it has been shown that organic sulfate can contribute up to $54 \%$ of the total sulfur present in soils (Freney et al., 1962) and up to $30 \%$ of the total sulfur present in freshwater lake (King and Klug, 1980), work done in this study shows that approx. $94 \%$ of the soluble sulfate present in sediment of Third Sister Lake supernatant is inorganic. This was determined by ion exchange chromatography on a $5 \mathrm{~cm}$ Dowex 1 column with $\mathrm{NaI}$ as elutant. Under these conditions, organic sulfate in the form of polysaccharide sulfate ester does not elute. This was demonstrated with the use of condroitin sulfate, a naturally occurring substituted polysaccharide. Using this method the sulfate present in five samples of Third Sister Lake sediment supematant (centrifuged at $10,000 \mathrm{~g}$ for $10 \mathrm{~min}$ ) was found to be $90-100 \%$ inorganic with an average of $94 \%$. Because of this and other uncertainty factors inherent in the estimations described here, sediment supernatant sulfate was considered inorganic.

Inorganic sulfate was determined on centrifuge supernatant and on samples shaken for $30 \mathrm{~min}$ with $\mathrm{pH} 7$ phosphate buffer (Lowe, 1964). Sulfate was also determined turbimetrically for epilimnetic water and for hypolimnetic water in contact with sediment as $\mathrm{BaSO}_{4}$ following filtration through prewashed $0.45 \mu$ membrane filters. Prior to determination $25 \mathrm{ml}$ samples were concentrated to $10 \mathrm{ml}$.

\section{Determination of cysteine in sediment}

Cysteine was determined on centrifuged sediment samples extracted for $30 \mathrm{~min}$ on a reciprocating shaker with $\mathrm{pH} 10$ phosphate buffer of ionic strength of 1.2 and with pH 12 phosphate buffer. Sediment samples were then centrifuged as above and the supernatant was oxidized with performic acid (Moore, 1962) which converts cysteine or cystine to cysteic acid. The oxidation mixture was then lypholized, hydrolized for $20 \mathrm{~h}$ at $105^{\circ} \mathrm{C}$ in $6 \mathrm{~N} \mathrm{HCl}$ and lypholized a second time. The residue was taken up in citrate buffer $(0.125 \mathrm{M}$ citric acid, $0.1 \mathrm{~N} \mathrm{NaOH}, 0.1 \mathrm{~N}$ $\mathrm{NaCl} .0 .1 \%$ phenol) of $\mathrm{pH} 3.45$ and applied to a $50 \times 1 \mathrm{~cm}$ column of $100-200$ mesh Dowex 1 equilibrated with citrate buffer. Cysteic acid eluted at $60-66 \mathrm{ml}$. Two $\mathrm{ml}$ fractions collected between 46 and $80 \mathrm{ml}$ were color developed by standard ninhydrin procedure (Rosen. 1957) using $0.5 \mathrm{ml}$ pH 5.2 acetate buffer, $0.5 \mathrm{ml}$ ninhydrin solution. heating for $15 \mathrm{~min}$ and diluting to a final volume of $10 \mathrm{ml}$. The data were integrated and compared to a standard curve.

\section{Determination of protein and free amino acids}

Total protein in terms of leucine equivalents was determined on sediment which had been extracted for $30 \mathrm{~min}$ with pH 10 phosphate buffer $\left(0.05 \mathrm{M} \mathrm{Na}_{2} \mathrm{HPO}_{4}\right.$ adjusted with $\mathrm{HCl}$ ) centrifuged for $10 \mathrm{~min}$ at $10.000 \mathrm{~g}$. hydrolized in sealed ambules purged with nitrogen for $20 \mathrm{~h}$ at $105^{\circ} \mathrm{C}$ and color developed by the method given for cysteic acid. Free amino acids were determined in the same way except that the hydrolysis step was omitted. Before determination. all samples were made alkaline and kept over concentrated $\mathrm{H}_{2} \mathrm{SO}_{4}$ in cacuo for $24 \mathrm{~h}$ to remove ammonia which is ninhydrin positive. Hypolimnetic protein and free amino acids were also determined monthly at Third Sister Lake.

\section{Organic carbon}

Organic carbon was determined on $\mathrm{pH} 10$ phosphate buffer extract (centrifuged $10,000 \mathrm{~g}$ ) of selected samples of sediment. Selected lake water samples filtered through $0.45 \mu$ membrane filters were also run. A Beckman Carbonaceous Analyzer was used for the determination.

\section{Oxidation-reduction potential}

Eh measurements of fresh lake sediment were obtained on $10 \mathrm{ml}$ aliquots of homogenized sediment transferred directly into $14 \times 54 \mathrm{~mm}$ polyethylene tubes taking care to avoid inclusion of air bubbles. A rubber stopper attached with micro Eh and reference electrodes was then inserted into each tube. After 30 min of closed circuit equilibration, readings were taken. The Eh electrode was platinum and the reference was $\mathrm{Ag}-\mathrm{AgCl}$ with $0.1 \mathrm{KCl}$. The platinum electrode was treated with $5 \mathrm{~N} \mathrm{HNO}_{3}$ and distilled water before each measurement.

\section{$p H$}

$\mathrm{pH}$ was determined with a combination $\mathrm{pH}$ electrode and read on an Orion 801 digital $\mathrm{pH}$ meter after $10 \mathrm{~min}$ of equilibration.

\section{Oxygen and temperature}

Oxygen and temperature at various sampling station depths were determined in situ with a galvanic lead-silver electrode and thermistor probe attached to a sounding line. Temperature was read directly from a Yellow Springs model 8400 Thermistor-Thermometer while galvanic response was read from a standard microammeter and later converted to $\mathrm{mg} \mathrm{l}^{-1}$ oxygen.

\section{Bacteria enumeration}

Enumeration of sulfate reducers and proteolytic bacteria were made using standard anaerobic roll tube techniques (Hungate, 1950, 1969, 1978). In brief 2-5 ten-fold dilutions were performed on $0.5 \mathrm{ml}$ of homogenized sediment. Exactly $0.5 \mathrm{ml}$ of the successive tenfold dilutions was inoculated into tubes containing sulfate-reducing and proteolytic media and rolled out. The medium used for enumeration

Table 1. Medium for enumeration of sulfate reducing bacteria

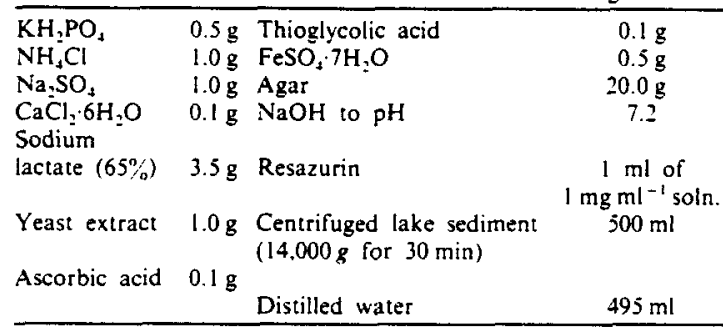


Table 2. Medium for enumeration of proteolytic bacteria

\begin{tabular}{lc}
\hline Yeast extract & $2.0 \mathrm{~g}$ \\
Nutrient broth & $2.0 \mathrm{~g}$ \\
$K, \mathrm{HPO}_{4}$ & $1.7 \mathrm{~g}$ \\
$\mathrm{KH}, \mathrm{PO}_{4}$ & $0.7 \mathrm{~g}$ \\
Agar & $20.0 \mathrm{~g}$ \\
Centrifuged lake sediment & $500 \mathrm{ml}$ \\
$(14.000 \mathrm{~g}$ for $30 \mathrm{~min})$ & \\
Resazurin & $1 \mathrm{ml}$ of $1 \mathrm{mg} \mathrm{ml}{ }^{-1}$ soln. \\
Mineral and fatty & \\
acid solution & $20 \mathrm{ml}$ \\
Distilled water & $480 \mathrm{ml}$ \\
\hline
\end{tabular}

of sulfate reducers was similar to that used by Postgate (1963) and is given in Table 1. All tubes were gassed out with $100 \%$ nitrogen passed through a heated reduced copper column to remove residual oxygen.

Medium for the enumeration of proteolytic bacteria was similar to that used by Siebert and Toerien (1969) and is given in Table 2. A reducing agent, cysteine $\mathrm{HCl} \cdot \mathrm{H}_{2} \mathrm{O}$ $(0.2 \mathrm{~g})$ was added to the medium after deoxygenation with nitrogen as above. Before inoculation each roll tube containing $4.0 \mathrm{ml}$ of proteolytic medium was injected with $0.5 \mathrm{ml}$ of sterilized skim milk and 1 drop of $5 \%$ sodium sulfide. The skim milk was prepared in a concentrated form by the addition of $5 \mathrm{~g}$ of dried milk solid to $25 \mathrm{ml}$ distilled water. After adding the milk to a roll tube, the air was displaced with $\mathrm{O}_{2}$ free nitrogen and the tube was stoppered and sterilized by heating in a boiling water bath for $15 \mathrm{~min}$. Milk sterilized in this way showed no growth with control tubes.

Successive ten-fold dilutions of sediment were made in tubes containing $4.5 \mathrm{ml}$ of the medium in Table 3 . As with the medium above, the dilution media was heated to boiling while bubbling through $\mathrm{O}$, free nitrogen before reducing agents were added. Gassed out tubes of this media were then prepared in advance. Proteolytic tubes were incubated for $24-36 \mathrm{~h}$ and $23^{\circ} \mathrm{C}$. Colonies producing clear zones (indicating protein hydrolysis) were counted. Sulfate reducing tubes were incubated at $37^{\circ} \mathrm{C}$ for $10-14$ days before colonies producing black zones were counted.

\section{RESULTS}

\section{Oxygen and temperature}

A summary of oxygen and temperature data is found in Table 4. The oxygen concentration in the hypolimnion of Third Sister Lake decreased abruptly from April to May primarily because of dissimilative oxygen uptake and increased stability of the epilimnion resulting from thermal stratification and the resultant reduced mixing. Further stagnation (anoxia) resulted from increased stabilization of the thermocline and oxidation of organic materials below the photic zone.

\section{Eh and $p H$ of sediment}

Eh displayed no difinite seasonal variation al-

Table 3. Media for dilution of sediment samples

\begin{tabular}{lc}
\hline $\mathrm{KH}_{3} \mathrm{PO}_{4}$ & $1.0 \mathrm{~g}$ \\
$\mathrm{MgSO}_{4}$ & $0.0 \mathrm{~g}$ \\
$\mathrm{NH}, \mathrm{Cl}$ & $1.0 \mathrm{~g}$ \\
Yeast extract & $1.0 \mathrm{~g}$ \\
Ascorbic acid & $0.1 \mathrm{~g}$ \\
Thioglycolic acid & $0.1 \mathrm{~g}$ \\
Resazurin & $\mathrm{I} \mathrm{ml} \mathrm{of} 1 \mathrm{mg} \mathrm{ml}$ \\
Distilled water & $997 \mathrm{ml}$ \\
\hline
\end{tabular}

Table 4. Oxygen concentration and temperature Third Sister Lake surface and bottom waters April-August

\begin{tabular}{ccccccccc}
\hline & \multicolumn{3}{c}{ West $(15 \mathrm{~m})$} & \multicolumn{3}{c}{ East $(10 \mathrm{~m})$} \\
\cline { 2 - 7 } Date & $O_{2}$ & Surface & \multicolumn{2}{c}{ Bottom } & \multicolumn{2}{c}{ Surface } & \multicolumn{2}{c}{ Bottom } \\
\hline 12 April & 12 & 11 & 6 & 5 & 11 & 11 & 5 & 5 \\
23 May & 9 & 23 & 0 & 5 & 9 & 23 & 1.5 & 8 \\
8 August & 9 & 21 & 0 & 6 & 9 & 21 & 0 & 8 \\
\hline
\end{tabular}

$\mathrm{O}_{2}$ - oxygen $\left(\mathrm{mg} \mathrm{^{-1 }}\right): \mathrm{T}$-temperature $(\mathrm{C}$ ).

though there was greater variation at the more shallow Third Sister East station. Twelve evenly distributed measurements from April to September gave a mean (vs $\mathrm{Ag} / \mathrm{AgCl} / 0.1 \mathrm{Cl}^{-}$) value of $-229 \mathrm{mV}$ with a standard deviation (SD) of 18.1 for the West station and $-230 \mathrm{mV}$ with a SD 26.2 for the East station. $\mathrm{pH}$ values obtained for these stations were 6.66 and 6.68 with a SD 0.08 for West and East stations respectively.

\section{Sulfate analyses}

Results of inorganic sulfate analyses of epilimnion and hypolimnion waters immediately adjacent to the sediment are summarized in Table 5. Within the confidence limits of the turbimetric analysis employed for these samples, the mean concentration of epilimnic and hypolimnic sulfate were essentially the same (3.9 and $4.3 \mathrm{mg} \mathrm{l}^{-1} \mathrm{~S}$ respectively). Table 6 includes results of sediment interstitial sulfate analyses (unextracted centrifuged samples) where sulfate concentrations were approximately the same at all three stations with an average of $2.3 \mathrm{mg} \mathrm{l}^{-1} \mathrm{~S}$. Samples of sediment shaken with $\mathrm{pH} 7$ buffer for $30 \mathrm{~min}$ prior to centrifugation averaged $10.5 \mathrm{mg} \mathrm{l}^{-1} \mathrm{~S}$. It is not known if this relatively high value represents desorbed sulfate or sulfate resulting from oxidation of ferrous sulfide or a combination of both. Within this context, the question arises as to which value best represents the concentration of sulfate which is metabolically available to Desulfovibrio for dissimilatory sulfate reduction under the existing environmental conditions. It seems reasonable to conclude that the phosphate buffer extract average of $10.5 \mathrm{mg} \mathrm{l}^{-1} \mathrm{~S}$ represents an unreasonably high upper limit because (1) extraction with shaking involves a greater risk of sediment sulfide oxidation and (2) sulfate extractable with phosphate may not be available to Desulfovibrio

Table 5. Summary of water sulfate data Third Sister Lake*

\begin{tabular}{lccccc}
\hline & $\begin{array}{c}\text { No. of } \\
\text { deter. }\end{array}$ & Max & Min & Mean & SD \\
\hline Epilimnion & 10 & 4.9 & 2.9 & 3.9 & 0.68 \\
Hypolimnion & 10 & 4.7 & 3.5 & 4.3 & 0.39 \\
\hline
\end{tabular}

*See text for description of method. Results expressed as sulfur.

Table 6. Summary of interstitial sulfate data Third Sister and Frain's Lakes*

\begin{tabular}{lccc}
\hline & $\begin{array}{c}\text { No. of } \\
\text { deter. }\end{array}$ & Mean & SD \\
\hline Third Sister W. & 9 & 2.2 & 0.29 \\
Third Sister E & 9 & 2.4 & 0.19 \\
Frain's & 3 & 2.3 & 0.12 \\
\hline
\end{tabular}

"See text for description of method. Results expressed as sulfur 
Table 7. Mean pH 10 extracted soluble protein and free amino acid content of sediment

\begin{tabular}{lccccc}
\hline \multicolumn{1}{c}{ Station } & $\begin{array}{c}\text { No. of } \\
\text { determinations }\end{array}$ & $\begin{array}{c}\text { Protein }+ \text { FAA } \\
\left(\mathrm{mg} \mathrm{l}^{-1}\right)\end{array}$ & $\begin{array}{c}\text { Protein } \\
\left(\mathrm{mg} \mathrm{l}^{-1}\right)\end{array}$ & $\begin{array}{c}\text { FAA } \\
\left(\mathrm{mg} \mathrm{l}^{-1}\right)\end{array}$ & $\begin{array}{c}0 \\
\text { Protein }\end{array}$ \\
\hline West & 6 & 176 & 127 & 49 & 72 \\
East & 6 & 148 & 110 & 38 & 74 \\
Frain's & 3 & 156 & 110 & 46 & 70 \\
Mean total & 155 & 111 & +4 & $7 !$ \\
\hline
\end{tabular}

due to spacial hindrance within mineral and organic matrices of the sediment. Based on this and kinetic bioassay results to be discussed later, the centrifuged sediment supernatant (interstitial water) sulfate values summarized in Table 6 were used to calculate sulfate reduction velocities.

\section{Carbon}

Sediment organic carbon extracted with $\mathrm{pH} 10$ phosphate buffer was quite variable at both Third Sister stations. The mean organic carbon concentrations were 220 and 159 for the West and East stations respectively with SD of 36 and $29 \mathrm{ppm}$ organic carbon. The range of membrane filtered $(0.45 \mu)$ surface and bottom samples was approx. $6-11 \mathrm{mg} \mathrm{l}^{-1}$ with maxima occurring in mid May, early June and late September.

\section{Protein and free amino acids}

Total hypolimnetic protein + free amino acids were monitored monthly during the April-October period. Concentrations at the two Third Sister stations were highly correlated $\left(r^{2}=0.9\right)$ with maxima in mid April and mid September of approx. 3.5 and $4.5 \mathrm{mg} \mathrm{l}^{-1}$ respectively. A minimum of about $2 \mathrm{mg} \mathrm{l}^{-1}$ occurred at both stations near 1 June. The sharp decrease in soluble protein and free amino acids from mid April to mid May could have been due to rapid decomposition of protein introduced by spring turnover. This increase observed between June and mid July may have been due to organic material introduced from algal growth through sedimentation.

Total protein and free amino acid content of sediment extracted with $\mathrm{pH} 10$ phosphate buffer for $30 \mathrm{~min}$ prior to centrifugation is summarized in Table 7. There was no apparent seasonal variation in sediment protein or free amino acids during the sampling period and concentrations were quite variable at all stations as were the concentrations of sedimentary organic carbon.

\section{Cysteine analysis}

Cysteine samples extracted at $\mathrm{pH} 10$ averaged $0.26 \mathrm{mgl}^{-1}$ cysteine sulfur with a range of

Table 8. Summary of cysteine values $\left(\mathrm{mg} \mathrm{l}^{-1}\right.$ ) obtained by $\mathrm{pH} 12$ extraction and centrifuging of sediment*

\begin{tabular}{lccc}
\multicolumn{4}{c}{ extraction and centrifuging of sediment* } \\
\hline \multicolumn{1}{c}{ Station } & $\begin{array}{c}\text { No. of } \\
\text { determinations }\end{array}$ & Mean & SD \\
\hline Third Sister West & 8 & 2.5 & 1.0 \\
Third Sister East & 8 & 1.8 & 0.5 \\
Frain's Lake & 4 & 1.1 & 0.3 \\
\hline
\end{tabular}

*See texi for description of method. Results expressed as sulfur.
$0-0.7 \mathrm{mg} \mathrm{l}^{-1} \mathrm{~S}$. Extraction of sediment at $\mathrm{pH} 12$ yielded higher values (as shown in Table 8 ) ranging from 0.7 to $3.7 \mathrm{mg} \mathrm{l}^{-1}$ sulfur with means of $2.5,1.8$ and 1.1 for West, East and Frain's station respectively. The higher levels obtained at $\mathrm{pH} 12$ are due to the fact that the negative carboxylate ion form of amino acids which predominates at higher $\mathrm{pH}$ has a reduced tendency to bind to negatively charged clay minerals at high $\mathrm{pH}$. The $\mathrm{pH} 12$ extracted cysteine values were used in calculating putrefaction rates because these agreed more closely with kinetic bioassay results as discussed later.

\section{Sulfate reduction rates}

Sulfate reduction variability at the two stations is summarized in Fig. 3 and are similar to rates observed in other freshwater lakes: Chebotarev et al. (1974) $0.5-18.4 \mathrm{mg} \mathrm{Sl}^{-1}$ day $^{-1}$; Chebotarev (1974) 6.0-12.9 $\mathrm{mg} \mathrm{Sl}^{-1} \mathrm{day}^{-1}$; Sorokin (1962) 0.02-2.2 mg $\mathrm{S}^{-1}$ day $^{-1}$; Ingvarsen et al. (1981) $2.6-17.6 \mathrm{mg} \mathrm{S} \mathrm{l}^{-1}$ day $^{-1}$; Sahalova (1968) $1.8 \mathrm{mg} \mathrm{S} \mathrm{I}^{-1}$ day $^{-1}$.

No apparent seasonal variation pattern was observed at either West or East station for sulfate reduction nor was sulfate reduction at West station highly correlated with that of East station $\left(r^{2}=0.15\right)$. The most characteristic seasonal feature of sulfate reduction was its very great variability. It has been
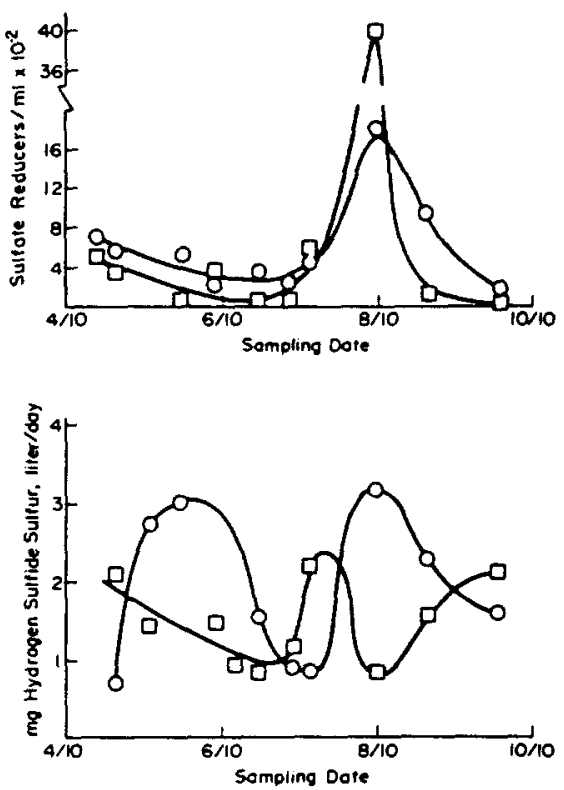

Fig. 3. Comparison of seasonal sulfate reduction and numbers of sulfate reducers in sediment of Third Sister Lake. $O$ West Station; $\square$ East Station. 

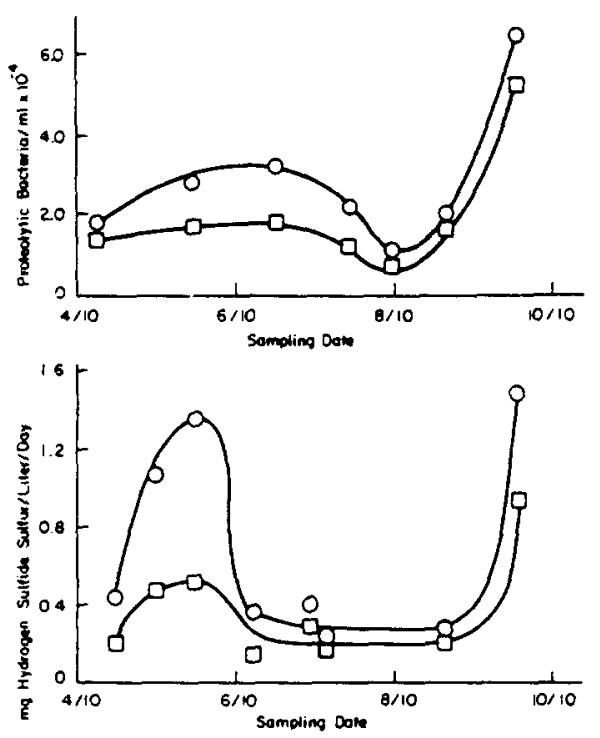

Fig. 4. Comparison of seasonal cysteine decomposition and numbers of proteolytic bacteria in sediment of Third Sister Lake. O West Station; $\square$ East Station.

demonstrated by many workers that sulfate and organic carbon may influence sulfate reduction rates. The concentration fluctuations of these substances at the two Third Sister stations, due in part to differences in depth and proximity to the littoral zone, may account for the low correlation in sulfate reduction between West and East stations. The approx. $40 \%$ lower rate at Frain's Lake can be attributed in part to the pulpy, relatively low density of its upper sediment even though Frain's is a more eutrophic lake.

\section{Putrefaction rate}

Putrefaction (cysteine decomposition) rates measured at Third Sister Lake are summarized in Fig. 4. Rates at West station were consistently higher than those at East station. This may be related to the earlier seasonal attainment of anoxia at West station, as indicated in Table 4. Unlike sulfate reduction, seasonal variations for putrefaction (cyteine decomposition) at West and East stations were quite similar with maxima and minima occurring at the same time. The seasonal correlation between West and East stations is high $\left(r^{2}=0.81\right)$. No putrefactive hydrogen sulfide production data from other investigations are available for comparison with these data.

\section{Relative importance of sulfate reduction and putre- faction}

Total combined hydrogen sulfide production due to both hydrogen sulfide production processes averaged 2.2 and $1.2 \mathrm{mg} \mathrm{S}^{-1}$ day $^{-1}$ for samples collected at Third Sister and Frains Lakes respectively. The range represented by these mean values was $0.9-4.7 \mathrm{mg} \mathrm{Sl}^{-1} \mathrm{day}^{-1}$. In only one sample, taken in early August at East station, did putrefaction exceed sulfate reduction. Putrefaction was estimated to be only slightly less important than sulfate reduction at West station on two sampling dates in June and September. Putrefaction's contribution to hydrogen sulfide production varied from 5.1 to $53.0^{\circ}$, with an average of 27.6 and $18.3^{\circ}$ o for West and East stations respectively and $12.5 \%$ at Frain's Lake. The data indicate that (1) putrefaction can be quite significant in overall sedimentary hydrogen sulfide production and (2) that the relative importance of putrefaction in hydrogen sulfide production in extremely variable but due primarily to the variability in sulfate reduction.

\section{Bacteria enumeration}

Numbers of sulfate reducers averaged 4.6 and $6.1 \times 10^{2} \mathrm{ml}^{-1}$ sediment for West and East stations respectively. This is comparable to an average literature value of $10^{3} \mathrm{ml}^{-1}$ for relatively shallow freshwater lakes (Sokolova and Karovoika, 1968; Ivanov and Terebkova, 1959). Numbers of proteolytic bacteria averaged $1.9 \times 10^{-4} \mathrm{ml}^{-1}$ for both stations respectively which compares to an average literature value of $10^{5} \mathrm{ml}^{-1}$ for limnetic freshwater environments (Bagirov and Salmanov, 1970; Gunkel and Oppenheimer, 1963; Ivanov and Terebkova, 1959). West and East stations were highly correlated with respect to both sulfate reducers and proteolytic bacteria (Figs 3 and 4). Proteolytic numbers were higher at West station. The most notable changes in proteolytic numbers occurred during the period of 26 August to 26 September when a six-fold increase was observed at both stations. Sulfate reducers exhibited abrupt maxima on 9 August. During the 3 week period from mid July to mid August, large increases took place at both stations, the West station increasing four-fold to 1700 cells $\mathrm{ml}^{-1}$ while the East station increased seven-fold to 4000 cells $\mathrm{ml}^{-1}$. During the period of $10 \mathrm{July}-10$ September an approx. 100-fold increase took place at East station with an accompanying nine-fold increase at West station. This increase in numbers of sulfate reducers coincided with a very abrupt $100 \%$ increase in hypolimnetic soluble organic carbon at both stations from 6 to $12 \mathrm{mg}^{-1}$ between $10 \mathrm{July}$ and 10 September. However, since the East stations' response during this period was so much greater than West station's other factors must be involved. Correlation between rate of putrefaction and numbers of proteolytic bacteria were quite high at both Third Sister East $\left(r^{2}=0.88\right)$ and West $\left(r^{2}=0.74\right)$ stations as is apparent from Fig. 4. The correlations between sulfate reduction and sulfate reducing organisms are relatively low with values of 0.04 and 0.22 for East and West stations respectively. The small number of samples taken from Frain's Lake precludes correlation considerations for that station. Average bacterial enumerations for Frain's Lake samples were $1.4 \times 10^{2}$ and $1.3 \times 10^{4}$ cells $\mathrm{ml}^{-1}$ for sulfate reducers and proteolytic bacteria respectively.

The wet-weight density of the samples taken from 
Third Sister Lake ranged from $1.10 \mathrm{~g} \mathrm{ml}^{-1}$ at a depth of $0.5 \mathrm{~cm}$ to $1.30 \mathrm{~g} \mathrm{ml}^{-1}$ at a depth of $4 \mathrm{~cm}$. Average density of the final homogenate was $1.20 \mathrm{~g} \mathrm{ml}^{-1}$. The average density of Frain's Lake samples was $1.1 \mathrm{~g} \mathrm{ml}^{-1}$.

\section{DISCUSSION}

\section{Evidence of the importance of putrefaction}

Prior to this study the evidence for significant hydrogen sulfide production from protein in lake sediment was indirect. Novazhilova and Berezina (1968) noted at three sampling stations that, although high concentrations of hydrogen sulfide were found in sediment (30-85 $\mathrm{mg} \mathrm{l}^{-1}$ ), only 200 sulfate reducing bacteria $\mathrm{g}^{-1}$ sediment were found. Because of the high numbers of saprophytes. most of the hydrogen sulfide present was attributed to their actions. Gunkel and Oppenheimer (1963) found $10^{5}$ cells $g^{-1}$ sediment capable of producing hydrogen sulfide from cysteine in marine sediment while only about $10^{3}$ sulfate reducers $\mathrm{g}^{-1}$ were observed. They associated the high numbers of putrefying bacteria with sulfide produced in laboratory incubations which could not be accounted for by loss of sulfate. Another laboratory incubation by Gunkel and Oppenheimer (1963) indicated organic sulfur was the source of approx. $5 \%$ of the total sulfide produced. The organic sulfur was not characterized. Nriagu (1968) calculated the amount of organic sulfur which should be present in sediment based on sulfur content of aquatic plants and microorganisms. Since considerably less was actually found in the sediment, it was suggested that the difference $(45 \%)$ might represent that portion of hydrogen sulfide formed from putrefactive processes. Koyama and Sugawara (1953) found more mineralized sulfide in stoppered bottle experiments than could be accounted for by sulfate depletion. In addition a sample of sediment digested with $\mathrm{HCl}$, leached and washed with distilled water, was added to nutrient media free of sulfur. After incubation with a sample of sediment, vigorous sulfide generation was observed suggesting that organic sulfur contributes substantially to the formation of hydrogen sulfide in the presence of relatively high concentrations of sulfate.

The present investigation supports these early observations by providing for the first time direct experimental evidence that putrefaction can contribute significantly to overall hydrogen sulfide production in anoxic freshwater sediment, producing, on a seasonally averaged basis, 13 and $23 \%$ of the total hydrogen sulfide produced in two different eutrophic Southeast Michigan lakes, with a seasonal maximum of $53 \%$.

\section{Determination of natural substrate availability in sedi. ment}

The accuracy of hydrogen sulfide production estimates from sulfate reduction and putrefaction depends to the greatest extent on knowledge of the metabolic availability of the primary hydrogen sulfide precursors, anionic sulfate and cysteine respectively. Availability is a function of substrate species and physical state which in turn are regulated by many complex environmental factors. Soil scientists have been concerned with this question for some time and most methods of soil analyses involve some kind of extraction of the substrate being investigated. The difficulty of obtaining meaningful values for sulfate availability in soils is widely known and documented (Freney et al., 1969). Air filtration of anoxic sediments containing ferrous sulfide inevitably results in over-estimation of sulfate due to oxidation of sulfide. In the present work a $\mathrm{pH} 12$ phosphate buffer procedure yielded a sediment sulfate concentration of $10.5 \mathrm{mg} \mathrm{S}^{-1}$ which is $2-4$ times that observed in the water immediately adjacent to the sediment. Supernatant from centrifuged sediment averaged $2.0 \mathrm{mg} \mathrm{S}$ $1^{-1}$. In order to validate the described analytical procedures as a measure of sulfate availability for Desulfovibrio desulfuricans the bioassay technique of Wright and Hobbie (1966) was applied. This procedure was also used to assess the accuracy of cysteine concentrations obtained from cysteine analysis (pH 12 phosphate buffer extraction and subsequent chromatographic analysis). The bioassay method involves the determination of rates at various added substrate concentrations in a series of diluted and undiluted samples. The bioassay analyses yielded $2.07 \mathrm{mg} \mathrm{Sl}^{-1}$ whereas the mean chemically determined value of the sediment samples was $2.3 \mathrm{mg} \mathrm{S} \mathrm{I}^{-1}$. For cysteine the bioassay and mean analytical values were 1.74 and $2.5 \mathrm{mg} \mathrm{Sl}^{-1}$ respectively. Bioassay results suggest that substrate concentrations used to calculate rates are reasonable values but that these values may be somewhat high relative to what is actually metabolically available.

\section{Sulfate reduction and putrefaction}

The relatively abrupt seasonal fluctuations and variations observed in sulfate reduction at West and East stations contrast sharply with putrefaction results in which variation in hydrogen sulfide production was considerably less and correlation between West and East stations was very high. The set of factors controlling putrefaction appear to be much less variable than those controlling sulfate reduction. This may be due to the fact that there is competition by other organisms for the low molecular weight organic substances required by sulfate reducers. In addition, the availability of these compounds may be subject to greater fluctuations than protein and amino acids.

\section{Numbers of organisms}

During the April-September sampling period abrupt changes in numbers of organisms were ob. served for sulfate reducers at both stations. During the period of 10 July-9 October an approx. 100-fold increase took place at East station with an accom- 
panying nine-fold increase at West station. The increase in numbers is probably a response to increases in available organic compounds from photosynthetic activity and the accompanying die-off of primary producers (algae) and other organisms. This increase coincides with a very abrupt $100 \%$ increase in soluble organic carbon content of the hypolimnetic waters at both stations from 6 to $12 \mathrm{mg} \mathrm{Cl}^{-1}$. However, since the East station's response during this period was so much greater than West station, other factors must be involved. The difference may be related to differences in depth of the two stations. East station, being at only $9 \mathrm{~m}$ receives not only more available organic carbon in the form of particulate, colloidal and sorbed matter (due to reduced assimilative and dissimilative breakdown and utilization in the shorter $9 \mathrm{~m}$ water column), but also must receive a greater portion of trace nutrients such as amino acids and other substances which have been shown to be strong growth stimulating factors for desulfuricans (Kadota and Miyoshi, 1963).

\section{Parametric correlations}

Computations of correlation coefficients $\left(r^{2}\right)$ obtained from seasonal variation of selected parameters related to hydrogen sulfide productions showed very good direct associations between cysteine decomposition and proteolytic bacteria numbers for both stations $\left(r^{2}=0.74\right.$ and 0.88$)$. Although the correlation coefficients for the relationship between sulfate reduction and numbers of sulfate reducers was not significant at either station over the period April-September $\left(r^{2}=0.22\right.$ and 0.04$)$, there are shorter periods for which the correlation is good. Between 10 July and 25 September there is quite good correlation at West station. However at West station between 27 April and 10 July the number of sulfate reducers was relatively constant while a four-fold increase was observed in sulfate reduction. For East station there is a good correlation during the period 27 April-30 June. After that a peak in sulfate reduction was observed at about 15 July with a subsequent immediate decrease to a minimum on 9 August. The overall poor correlation between sulfate reduction and numbers of sulfate reducers is probably due to the fact that sulfate reducers such as Desufovibrio are quite subject in their activities to modification in the chemical environment.

A significant inverse correlation was observed between numbers of sulfate reducers and proteolytic bacteria. A peak in sulfate reducers on 10 August corresponded exactly with the minimum observed in proteolytic bacteria numbers. Since proteolytic bacteria normally occurred in numbers 100 times greater than sulfate reducers, the increase in sulfate reducing bacteria may be a result of decreased competition for nutrients.

No significant correlations existed between organic carbon contert of hypolimnetic waters adjacent to the sediment and number of sulfate reducers, sulfate reducing activity. proteolytic bacteria or cysteine decomposition, nor was any significant correlation observed between the protein content of these waters and proteolytic bacteria or cysteine decomposition. Sulfate concentration in the sediment did not correlate well with sulfate reduction or sulfate reducing bacteria over the entire April-September period. Good correlations among some of these parameters were observed for shorter periods of time, however. The fact that correlations were not more significant is confirmation of the complexity of the environmental factors controlling natural sulfur transformation.

Because of its unique properties, hydrogen sulfide is able to greatly influence the biological, chemical and physical characteristics of the aquatic environment. Recent evidence (cited earlier) also suggests the importance of natural sources of hydrogen sulfide with respect to possible acid rain and atmospheric health effects and emphasizes the importance of understanding hydrogen sulfide production so that consequences of environmental alteration can be more easily forecast or that control measures can be properly imposed. This paper is the first of several describing results of our studies designed to help elucidate the chemical ecology of hydrogen sulfide production.

Acknowledgements - This study was supported in part by National Institute of Health and Environmental Protection Agency grants 5TO1-EC00030 and 5P3-WP-177, respectively.

\section{REFERENCES}

Bagirov V. I. and Slamonov M. A. (1970) Microorganisms in bottom deposits of the Caspian Sea. Microbiology (USSR) 39, 606

de Barjac H. (1952) Annls Inst. Pasteur 82, 623.

Bass Becking L. M. G., Kaplan I. R. and Moore D. (1960) Limits of the natural environment in terms of $\mathrm{pH}$ and oxidation-reduction potentials. J. Geol. 68, 243-284.

Chebotarev E. N. (1974) Microbiological hydrogen sulfide formation in the freshwater Karst Lakes, Bolshoi. Kichier and Chernyi Kichier. Microbiology (USSR) 43, 939.

Desnuelle P. and Grand L. (1943) Bull. Soc. chem. Biol. 25, 1133.

Dimick R. E. (1952) The effects of kraft mill waste liquors and some of their components on certain salmonid fishes of the Pacific Northwest. National Council for Stream Improvement. Technical Bulletin 51.

Frederick L. R., Starkey R. L. and Segal W. (1957) Decomposability of some organic sulfur compounds. Soil Sci. Am. Proc. 21, 287-292.

Freney J. R. (1967) Sulfur containing organics. In Soil Biochemistry (Edited by McLaren A. D. and Peterson G. H.). Marcel Dekker, New York.

Freney J. R., Barrow N. J. and Spencer K. (1962) A review of certain aspects of sulfur as a soil constituent and plant nutrient. Plant Soil 17, 295-309.

Freney J. R., Melville G. E. and Williams C. H. (1969) Extraction, chemical nature and properties of soil organic sulfur. J. Sci. fd Agric. 20, 440.

Fromageat C. (1951) In The Enzymes (Edited by Sumner J. B. and Myrback K.). Academic Press. New York. 
Goldberg A. B., Maroulis P. J., Wilner L. A. and Bandy, A. R. (1981) Study of H,S emissions from a salt water marsh. Atmos. Entir. 15, 11-18.

Gunkel W. and Oppenheimer C. H. (1963) Experiments regarding the sulfide formation in sediment of the Texas Gulf Coast. In Marine Microhiology (Edited by Oppenheimer C. H.). Charles Thomas. Springfield, IL.

Hayder E. P.. Amberg H. R. and Dimick R. E. (1962) The effect of kraft mill waste components on certain salmonid fishes of the Pacific Northwest. Tech. Ass. Pulp Paper Ind. $35,545$.

Hitchcock D. R. (1980) Lung cancer, wetlands and hydrogen sulfide. Trace substituents in environmental HealthXIV. Proceedings of the 14 th Annual Conference, Columbia, MO.

Hitchcock D. R.. Spiller L. L. and Wilson W. E. (1980) Sulfuric acid aerosols and $\mathrm{HCl}$ release in coastal atmospheres: evidence of rapid formation of sulfuric acid particulates. Atmos. Encir. 14, 165-182.

Hobbie J. E. and Crawford C. C. (1969) Respiration corrections for bacterial uptake of dissolved organic compounds in natural waters. Limnol. Oceanogr. 14, 528-532.

Hungate R. E. (1969) Ecology of bacteria. In The Bacteria (Edited by Gunsalers I. C. and Stanier R. Y.), Vol. IV. Academic Press. New York.

Hungate R. E. (1979) A roll tube method for cultivation of strict anaerobes. In Methods in Microbiology $3 B$ (Edited by Norris J. R. and Ribbons D. W.), pp. 117-132. Academic Press, New York

Ingvarsen K., Zeikus J. G. and Brock T. D. (1981) Dynamics of bacterial sulfate reduction in a eutrophic lake. Appl. encir. Microbiol. 42, 1029-1036.

Ivanov M. V. (1956) Isotopes as aids in studies concerned with the intensity of sulfate reduction in Lake Belovod (Russ.) Mikrobiologia 25, 1956.

Ivanov M. V. (1968) Brief characterization of the principal bacterial groups of the sulfur cycle. In Microbiological Processes in the Formation of Sulfur Deposits. Israeli Program for Scientific Translation, Jerusalem.

Ivanov M. V. (1978) Influence of microorganisms and microenvironment on the global sulfur cycle. In Environmental Biogeochemistry and Geomicrobiology (Edited by Krumbein W. E.), pp. 46-61. Ann Arbor Science, Ann Arbor, MI.

Ivanov M. V. and Terebkova L. S. (1959) Study of microbiological processes of hydrogen sulfide formation in Lake Solenoe-I. Microbiology 28, 235-239.

Johnson C. M. and Arkley T. H. (1954) Microestimation of sulfur in plant materials, soils, and irrigation waters. Anal. Chem. 26, 1525.

Johnson C. M. and Nishita H. (1952) Microestimation of sulfur. Anal. Chem. 24, 736.

Kadota H. and Ishida Y. (1972) Production of volatile sulfur compounds by micro-organisms. A. Rev. Microbiol. 26, $127-138$.

Kadota H. and Miyoshi H. (1963) Organic factors responsible for the stimulation of growth of Desulfovibrio desulfuricans. Marine Microbiology (Edited by Oppenheimer C. H.). Charles Thomas, Springfield, IL.

King G. M. and Klug M. J. (1980) Sulfhydrolose activity in sediments of Wintergreen Lake, Kalamazoo County, Michigan. Appl. entir. Microbiol. 39, 950-956.

Koyama T. and Sugawara K. (1953) Sulfur metabolism in bottom muds and related problems. J. Earth Sci. Japn. 1, 24-34.

Lovatt Evans C. (1967) The toxicity of hydrogen sulfide and other sulfides. Q. Jl exp. Physiol. 52, 231.

Lowe L. E. (1964) An approach to the study of the sulfur status of soils and its application to selected Quebec Soils. Can. J. Soil Sci. 44, 176-179.
Moore S. (1963) On the determination of cystine as cysteic acid. J. biol. Chem. 238, 235

Nakai N. and Jensen M. L. (196-) The kinetic isotope effect in the bacterial reduction and oxidation of sulfur. Geochim. cosmochim. Acta 28, 1893-19!2.

Novozhilova M. A. and Berezina F. S. (1968) Character of the distribution of sulfate reducing and sulfur bacteria in the sediments of Lake Balkhash. Microbiology 37, $436-439$.

Nriagu J. O. (1968) Sulfur metabolism and sedimentary environment: Lake Mendota. Wisconsin. Limnol. Oceanogr. 13, 430-439.

Parker C. D. (1945) The corrosion of concrete. Aust. J. exp Biol. Med. Sci. 23, 81-98.

Parsons T. R. and Strickland J. D. H. (1962) On the production of particulate organic carbon by heterotrophic processes in sea water. Deep-Sea Res. 8 , $211-222$.

Phochon J., Coppier O. and Chan Y. T. (1951) Chim. Ind. 65, 496.

Postgate J. R. (1959) Sulfate reduction by bacteria. $A$. Rev. Microbiol. 13, 505-519.

Postgate J. R. (1963) Versatile medium for the enumeration of sulfate reducing bacteria. Appl. Microbiol. 11, 265.

Rosen H. (1957) A modified ninhydrin colorimetric analysis for amino acids. Archs biochem. Biophys. 67, 10-15.

Rice H., Nochumson D. H. and Hidy G. M. (1981) Contribution of anthropogenic and natural sources to atmos. pheric sulfur in parts of the United States

Salsbury R. L. and Merricks, D. L. (1975) Production of methanethiol and dimethyl sulfide by rumen microorganisms. Plant Soil 43, 191-209.

Servant J. and Delaport M. (1982) Daily variations of the $\mathrm{H}_{2} \mathrm{~S}$ content in atmospheric air at ground-level in France. Atmos. Entir. 16, 1047-1052.

Siebert M. L. and Toerien D. F. (1969) The proteolytic bacteria present in the anaerobic digestion of raw sewage sludge. Water Res. 3, 24l-250.

Sorokin Yu. I. (1962) Experimental investigation of bacterial sulfate reduction in the Black Sea using $\mathrm{S}^{35}$. Microbiology (USSR) 31, 320-335.

Smith L. L. et al. (1976) Effect of hydrogen sulfide on fish and invertebrates. EPA 600/3-76-062a.

Sokolova G. A. and Karovoika G. I. (1968) Physiology and geochemical activity of Thiobacilli. In Microbiological Processes in the Formation of Sulfur Deposits. Israeli Program for Scientific Translation, Jerusalem.

Steinbergs A., lismaa O., Freney J. R. and Barrow J. H. (1962) Determination of total sulfur in soil and plant material. Anal chim. Acta 27, 158-164.

Tarr H. L. A. (1933) The enzymic formation of hydrogen sulfide by certain heterotrophic bacteria. Biochem. J. 27, 1869-1874.

Taylor C. B. and Hutchinson G. H. (1947) J. soc. Chem. Ind., Lond. 66, 54

Van Horn W. M. and Honzal R. F. (1955) The effect of pulp and paper mill wastes on aquatic life. Fifth Ontario Industrial Wastes Conference, Ontario Water Resources Commission.

Vanderpost J. M. (1972) Bacterial and physical characteristics of Lake Ontario sediment during several months. Proc. 15th Conf. Great Lakes Res., 198-213.

Wright R. T. and Hobbie J. E. (1966) Use of glucose and acetate by bacteria and algae in aquatic ecosystems. Ecology 47, 447-464.

Young L. and Maw G. A. (1958) The Metabolism of Sulfur Compounds. Methuen, London.

Zinder S. H. and Brock T. D. (1978) Methane, carbon dioxide, and hydrogen sulfide production from the terminal methial group of methionine by anaerobic lake sediments. Appl. entir. Microbiol. 35, 344-352. 